\title{
SIDE CHAIN REACTIVITIES OF GLUCOAMYLASE G2 FROM ASPERGILLUS NIGER EVALUATED BY GROUP-SPECIFIC CHEMICAL MODIFICATIONS
}

\author{
by
}

\author{
KJELL HÄKANSSON and BIRTE SVENSSON
}

Department of Chemistry, Carlsberg Laboratory, Gamle Carlsberg Vej 10, DK-2500 Copenhagen Valby

\begin{abstract}
Keywords: Difference spectroscopy, acarbose, 1-carboxamidomethyl-histidine, endoglycosidase $\mathbf{H}$, titration
\end{abstract}

\begin{abstract}
Treatment of glucoamylase G2 with large excesses of different group specific reagents resulted in modification of $25 \%$ of the histidyl, $15 \%$ of the tyrosyl, $20-40 \%$ of the arginyl, $30-50 \%$ of the lysyl and none of the methionyl residues. The modified groups were not critical since the various derivatives possessed from $50 \%$ to $100 \%$ residual enzymatic activity and retained the thermostability. Carboxamidomethylation occurred specifically at $\mathrm{His}_{254}$ with essentially no change of the kinetic parameters for hydrolysis of maltose and starch. Removal of the two $N$-linked sugar units by endoglycosidase $\mathrm{H}$ was similarly without effect on activity, thermostability and chemical reactivity of the histidyl residues. $\mathrm{H}^{+}$-titration revealed that glucoamylase $\mathrm{G} 2$ carries a lower net charge throughout the pH-range 3-11 than predicted from its amino acid composition.
\end{abstract}

\section{INTRODUCTION}

Glucoamylase G2 (1,4- $\alpha$-D-glucan glucohydrolase, EC 3.2.1.3) from Aspergillus niger is a highly water-soluble glycoprotein. It comprises the $512 \mathrm{~N}$-terminal residues of the 616 amino acid residues long $\mathrm{G} 1$ form and contains the $N$-glycosylated $\mathrm{Asn}_{171}$ and $\mathrm{Asn}_{395}$ as well as the highly $O$-glycosylated sequence $\operatorname{Ser}_{441}-\mathrm{Thr}_{511}(5$, $43,45)$. The two forms are equally active towards soluble substrates, but only $\mathrm{Gl}$ is able to degrade raw starch (47). A number of tryptophanyl residues and carboxyl groups involved in substrate binding and catalysis have been identified by chemical modification and sequencing $(8,9,42,46)$. The related enzymes, $\alpha$-amylase and $\alpha$-glucosidase, in addition possess critical histidyl residues $(2,6,11,13,14,19$, 23,38 ), but modification of glucoamylase by diethyl pyrocarbonate $(18,31,35)$ has only been found to decrease the affinity for soluble starch (18). In the light of the structural and functional similarities recognized recently for different starch-degrading enzymes $(9,20,41)$, the role of histidyl and other side chains was reinvestigated in A. niger glucoamylase. The observed poor reactivity of groups normally exposed in native proteins motivated a characterization of the ionization behaviour of glucoamylase G2 by potentiometric and spectrophotometric titration.

Abbreviations: DEP = diethyl pyrocarbonate; EDTA = ethylene diaminotetraacetic acid; G1, G2 = glucoamylase G1 and $G 2$, respectively $(5,43,45,47) ; \mathbf{R P}-H P L C=$ reverse phase high pressure liquid chromatography; Tris = 2-amino-2(hydroxymethyl)-1,3-propandiol. 


\section{EXPERIMENTAL}

\subsection{Materials}

Glucoamylase G2 was purified as previously described (47) from a commercial preparation from A. niger (gift from Novo Industries, Bagsvaerd, Denmark). Diethyl pyrocarbonate, iodoacetamide, iodoacetate, $O$-methylisourea, lactoperoxidase and trypsin were purchased from Sigma Chemical Co., St. Louis, MO; 2,3butanedione and trinitrobenzene sulfonic acid were from Fluka AG, Buchs, Switzerland, phenylglyoxal and 2-vinylpyridine from Janssen Chimica, Beerse, Belgium, methyl acetimidate from Pierce Chemical Co., Rockford, IL, and succinic anhydride from BDH Ltd., Dorset, England. Endoglycosidase H (EC 3.2.1.96) was from Boehringer Mannheim, Mannheim, FRG. $\left[{ }^{14} \mathrm{C}\right]$ iodoacetamide $[50-60 \mathrm{mCi} / \mathrm{mmol}]$ was supplied by Amersham International, Buckinghamshire, England. Maltose monohydrate, "System Glucose" kit and "Titrisol" 0.1 m $\mathrm{NaOH}$ were from Merck, Darmstadt, FRG. Acarbose was a generous gift from Drs. E. Truscheit, D. SCHMIDT and E. Möller, Bayer AG, Wuppertal, FRG.

\subsection{Analytlcal procedures}

Concentrations of glucoamylase G2 were determined spectrophotometrically employing $\varepsilon_{280}=1.09 \cdot 10^{5} \mathrm{M}^{-1} \cdot \mathrm{cm}^{-1}(8)$. Amino acid and glucosamine contents were analyzed as earlier described (43-45) and 1-carboxymethyl-histidine, which coeluted with proline, was quantified using the ninhydrin colour yield at $570 \mathrm{~nm}$ for serine (10). Peptide sequencing and identification of phenylthiohydantoins were performed on an Applied Biosystems model 470A gasphase sequenator and a Hewlett-Packard HPLC chromatograph, model 1084B equipped with a Novapak $^{\text {TM }} \mathrm{C}_{18}$ column (40).

Glucoamylase activity (47) was determined with maltose (15 mM) or starch (2\%) as substrate in $0.1 \mathrm{M}$ sodium acetate $\mathrm{pH} 4.3$ at $25^{\circ} \mathrm{C}$ and 37 ${ }^{\circ} \mathrm{C}$, respectively. $\mathrm{k}_{\text {cat }}$ and $\mathrm{K}_{\mathrm{m}}$ were derived from Eadie-plots of activities against maltose (0.5-4 $\mathrm{mM})$ and soluble starch (0.01-0.8\%) at the same temperatures. The thermostability was assessed essentially as described (42) at an enzyme concentration of $0.9 \mu \mathrm{M}$. Radioactivity was mea- sured with an LKB 1219 Rackbeta liquid scintillation counter using Dimilume-30 (United Technologies Packard) as scintillant.

Perturbation of the UV spectrum of glucoamylase G2 (8) obtained by addition of ligand in water $(5-10 \mu \mathrm{l})$ to a Millipore filtered protein solution was recorded at a scan rate of $0.1 \mathrm{~nm}$. $\mathrm{s}^{-1}$ using a Cary Model 219 spectrophotometer and double-chamber cuvettes.

\subsection{Chemical modifications}

$\mathrm{G} 2\left(1 \mathrm{mg} \cdot \mathrm{ml}^{-1}\right.$ in $0.1 \mathrm{M}$ sodium acetate $\mathrm{pH} 5.0$ or $0.1 \mathrm{M}$ sodium phosphate either $\mathrm{pH} 6.0$ or $\mathrm{pH}$ 7.0) was reacted with DEP (0.5-20 mM) for 40-60 $\mathrm{min}$ at room temperature (24). The formation of ethoxyformyl-histidine was followed spectrophotometrically at $242 \mathrm{~nm}$ using $\Delta \varepsilon=3,200$ $\mathrm{cm}^{-1} \cdot \mathrm{mol}^{-1}$ (34). Alternatively, $\mathrm{G} 2\left(1 \mathrm{mg} \cdot \mathrm{ml}^{-1}\right.$ in $0.1 \mathrm{M}$ sodium acetate $\mathrm{pH} 4.3$ or $0.1 \mathrm{M}$ sodium phosphate $\mathrm{pH} 7.0$ ) was incubated with $0.1 \mathrm{M}$ of iodoacetamide (or iodoacetic acid) for 5-6 days at $30{ }^{\circ} \mathrm{C}$ in the dark $(10,16)$. The control contained sodium azide $(0.05 \%)$. After removal of excess reagent by either dialysis or gel filtration the enzyme was isolated by affinity chromatography on acarbose-Sepharose (9). G2 (3 $\mathrm{mg} \cdot \mathrm{ml}^{-1}$ in $0.1 \mathrm{M}$ sodium acetate $\mathrm{pH}$ 5) was labelled with $\left[{ }^{14} \mathrm{C}\right.$ ]iodoacetamide $(0.1 \mathrm{M}, 690$ $\left.\mathrm{dpm} \cdot \mathrm{nmol}^{-1}\right)$ as above.

G2 $\left(1 \mathrm{mg} \cdot \mathrm{ml}^{-1}\right)$ was iodinated either by the lactoperoxidase reaction at $\mathrm{pH} 5.0$ in $0.1 \mathrm{M}$ sodium acetate $(25,26)$ or by a 15 fold molar excess of $\mathrm{I}_{2} / \mathrm{I}^{-}$in $0.1 \mathrm{M}$ sodium phosphate, $1 \mathrm{mM}$ $\mathrm{KI} \mathrm{pH} 8.0$ at $0{ }^{\circ} \mathrm{C} \mathrm{(3),} \mathrm{followed} \mathrm{by} \mathrm{dialysis.} \mathrm{For}$ nitration (37) $\mathrm{G} 2\left(5 \mathrm{mg} \cdot \mathrm{ml}^{-1}\right.$ in $0.2 \mathrm{M}$ sodium borate $\mathrm{pH} 8.2$ ) was incubated with tetranitromethane $(25 \mathrm{mM})$ at room temperature for 2 $h$, the derivative was purified by gel filtration followed by affinity chromatography (9). All these reactions took place in the dark.

To modify arginine equal volumes of G2 (1.8 $\mathrm{mg} \cdot \mathrm{ml}^{-1}$ in $0.2 \mathrm{M}$ sodium phosphate $\mathrm{pH} 8$ ) and phenylglyoxal $(0.32 \mathrm{M})$ were mixed $(48)$ and incubated for $1.5 \mathrm{~h}$ at $30^{\circ} \mathrm{C}$ followed by dialysis. Alternatively, G2 $\left(2 \mathrm{mg} \cdot \mathrm{ml}^{-1}\right.$, in $0.1 \mathrm{M}$ sodium borate $\mathrm{pH} \mathrm{8.0)}$ was treated with 2,3-butanedione $(0.1 \mathrm{M})(30)$. The activity was measured after 20 $h$ and the remaining arginine was determined by amino acid analysis on aliquots acidified imme- 
diately after removal (30).

Primary amino groups were succinylated at room temperature by addition of succinic anhydride as 7 portions over $60 \mathrm{~min}$ to $\mathrm{G} 2\left(1 \mathrm{mg} \cdot \mathrm{ml}^{-1}\right.$ in $0.1 \mathrm{M}$ sodium phosphate $\mathrm{pH} 8$ ) to maintain a 700 fold molar excess (7). The extent of modification was estimated by the trinitrobenzene sulfonic acid method (15) from the decrease in adsorbance at $420 \mathrm{~nm}$ compared to a control. The extent of $O$-acylation was not assessed. The amino groups of $\mathrm{G} 2$ were also reacted with methyl acetimidate $\left(0.04 \mathrm{M}\right.$ and $3 \mathrm{mg} \cdot \mathrm{ml}^{-1}$ of protein in $0.1 \mathrm{M}$ sodium borate $\mathrm{pH} 8.0$ and 9.0 ) for $1 \mathrm{~h}(33), \mathrm{KCNO}\left(0.24 \mathrm{M}\right.$ and $0.8 \mathrm{mg} \cdot \mathrm{ml}^{-1}$ of protein in $0.2 \mathrm{M}$ sodium borate $\mathrm{pH} 8.0$ ) (39) at $30^{\circ} \mathrm{C}$, and $O$-methylisourea $(0.4 \mathrm{M}$ and protein, $3 \mathrm{mg} \cdot \mathrm{ml}^{-1}$, in the $\mathrm{pH}$ range $\left.8.5-10.5\right)$ at $4{ }^{\circ} \mathrm{C}$ for $23 \mathrm{~h}(21,29)$.

In an attempt to oxidize methionines $\mathrm{G} 2(1.0$ $\mathrm{mg} \cdot \mathrm{ml}^{-1}$ in $0.5 \mathrm{~mm}$ EDTA, $0.1 \mathrm{M}$ sodium citrate pH 3.2) was treated with $\mathrm{H}_{2} \mathrm{O}_{2}(0.74 \mathrm{M})$ for $3 \mathrm{~h}$ at $30^{\circ} \mathrm{C}$. After dialysis against the same buffer containing $\mathrm{MnO}_{2}$ and then water (32) methionine contents were determined $(17,27)$.

Enzymatically active $N$-bromosuccinimide oxidized or carbodimide modified $G 2$ were prepared in the presence of acarbose as earlier described $(8,9,42,46)$.

\subsection{Enzymatic deglycosylation}

$\mathrm{G} 2\left(2.5 \mathrm{mg} \cdot \mathrm{ml}^{-1}\right.$ in $0.1 \mathrm{M}$ sodium citrate $\mathrm{pH}$ $5.0,0.1 \%$ sodium azide) was incubated with endoglycosidase $\mathrm{H}\left(0.1\right.$ units $\left.\cdot \mathrm{ml}^{-1}\right)$ (50) for $48 \mathrm{~b}$ at $37^{\circ} \mathrm{C}$. The released carbohydrate was removed by gel filtration on Bio-Gel P-30 in $5 \mathrm{mM}$ sodium acetate $\mathrm{pH}$.4.3.

\subsection{Preparation and purification of peptide fragments}

$\left[{ }^{14} \mathrm{C}\right]$ carboxamidomethyl-G2 prepared at $\mathrm{pH}$ 5.0 (see 2.3) or deglycosylated G2 were 2 pyridylethylated and digested with trypsin (43). The resulting fragments were separated on a Bio-Gel P-100 column followed by RP-HPLC using a Wide Pore $\mathrm{C}_{18}$ column (J.T. Baker Research Laboratories, Phillipsburg, NJ) (43, 44). Selected peptides were rechromatographed on a Vydac $218 \mathrm{TPb}$ column (43) eluted isocrat- ically at $13 \% 1$-propanol in $0.1 \%$ trifluoroacetic acid for $20 \mathrm{~min}$ followed by a linear gradient up to $22 \% 1$-propanol over $110 \mathrm{~min}$.

\subsection{Titration}

Potentiometric titrations (49) were carried out using a Radiometer autoburette $\mathrm{ABU} 13$, a PHM 64 pH meter and a GK 2321 C electrode (Radiometer, Denmark) in a water-jacketed vessel at $25^{\circ} \mathrm{C}$ under nitrogen. The $\mathrm{G} 2$ sample was exhaustively dialyzed against distilled water, freeze-dried and dissolved at a concentration of $5 \mathrm{mg} \cdot \mathrm{ml}^{-1}$ in distilled water. After Millipore filtration solid $\mathrm{KCl}$ was added to $0.1 \mathrm{M}$. A sample of $8 \mathrm{ml}$ was adjusted to $\mathrm{pH} 3.0$ by $0.1 \mathrm{M} \mathrm{HCl}$ and titrated with $0.1 \mathrm{M} \mathrm{NaOH}$ (Titrisol). $\mathrm{KCl}$ was added to the last dialysate which was used for solvent titration. The number of protons dissociated from $\mathrm{G} 2$ at a given $\mathrm{pH}$ was calculated from the difference between the uptake of base by the sample and solvent solutions.

Spectrophotometric titration (12) in $0.1 \mathrm{M}$ $\mathrm{KCl}$ was performed by adding increments of either $3 \mathrm{M}$ or $6 \mathrm{M} \mathrm{KOH}(0.1-200 \mu \mathrm{l})$ to $2.3 \mathrm{ml}$ of $\mathrm{G} 2\left(1 \mathrm{mg} \cdot \mathrm{ml}^{-1}\right) \cdot \mathrm{pH}$ was measured as above and difference spectra recorded with a Cary Model 219 spectrophotometer at a scan rate of 0.2 $\mathrm{nm} \cdot \mathrm{s}^{-1}$. A sample of denatured $\mathrm{G} 2$, prepared by boiling in water for $2 \mathrm{~min}$, was cleared by centrifugation and solid urea and $\mathrm{KCl}$ were added to the supernatant followed by dilution.

\section{RESULTS}

3.1. Ligand binding to glucoamylase at $\mathrm{pH} 8.0$

The glucoamylase from $A$, niger displays maximum activity near $\mathrm{pH} 4$ and very low activity above $\mathbf{p H} 6$. UV-spectral perturbation (Fig. 1A), however, allowed estimation of $\mathrm{K}_{\text {diss }}$ for the substrate maltose at $\mathrm{pH} 8.0$ from a Scatchard plot (Fig. IB), although this procedure is not strictly correct to apply because the ligand can occupy a number of both non-equivalent and overlapping sites $(1,28)$. The value of $\mathrm{K}_{\text {diss }}=2.4 \mathrm{mM}$ was in reasonable agreement with a $\mathrm{K}_{\mathrm{m}}$ of about $1 \mathrm{~mm}$ for maltose determined at $\mathrm{pH} 4.3$ (46), the peak shapes in the $280-300 \mathrm{~nm}$ range (Fig. 2 ) were also very similar in difference 

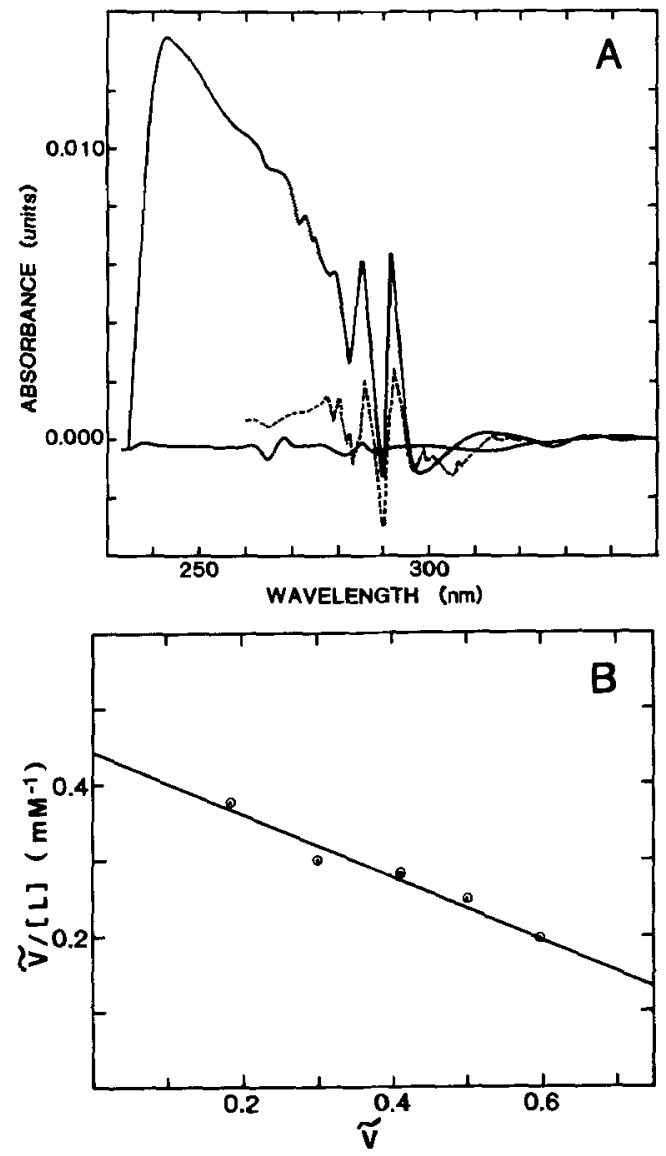

Figure 1. A) Difference absorption spectrum of G2 (13 $\mu \mathrm{M})$ induced at $\mathrm{pH} 8.0(0.1 \mathrm{M}$ sodium phosphate) by 12 $\mathrm{mM}$ maltose (-) and at $\mathrm{pH} 5.0(0.05 \mathrm{M}$ sodium acetate) by $15 \mathrm{~mm}$ maltose (- - )

B) A Scatchard plot based on the change in absorbance at $245 \mathrm{~nm}$ of $\mathrm{G} 2(13 \mu \mathrm{M})$ induced by the presence of 5 different concentrations of maltose $(0.51-3.00 \mathrm{mM})$ at $\mathrm{pH} 8.0$. v is the fractal change of the spectrophotometric signal and [L] the concentration of free ligand in the solution.

spectra induced by maltose at $\mathrm{pH} 5.0$ and 8.0 , respectively (Fig. 1A). The observed pH-dependence of the intensity of the perturbation presumably reflects that maltose is consumed by the enzyme at the lower $\mathrm{pH}$ value. Moreover, proportionality was observed at both $\mathrm{pH}$ values between the amount of added acarbose and the resulting absorbance differences (Fig. 2A and B) indicating a tight binding even at $\mathrm{pH} 8.0 . \mathrm{K}_{\text {diss, }}$, however, could not be calculated as above due to the low concentrations of free acarbose. Taken together, these results suggest that no gross conformational change of glucoamylase takes place between $\mathrm{pH} 4$ and 8 . Hence, valid information on structure/function relationships might also be gained from chemical modification experiments performed at $\mathrm{pH}$ 8.0.

\subsection{Chemical modifications of glucoamylase $\mathbf{G} 2$}

\subsubsection{Histidyl residues}

DEP substituted only one out of four histidines in i) G2, ii) a destabilized but enzymatically active G2 treated with $N$-bromosuccinimide to contain four oxindolealanyl residues $(8,42)$ or iii) $N$-deglycosylated $\mathrm{G} 2$ prepared as described in 2.4. In these three cases no effect on activity towards either maltose or soluble starch was observed (data not shown). All four histidyl residues easily underwent modification in heat denatured $\mathrm{G} 2$.

Iodoacetamide similarly alkylated one histidyl residue at $\mathrm{pH}$ values 4.3 (Table $\mathrm{I}$ ), 5.0 and

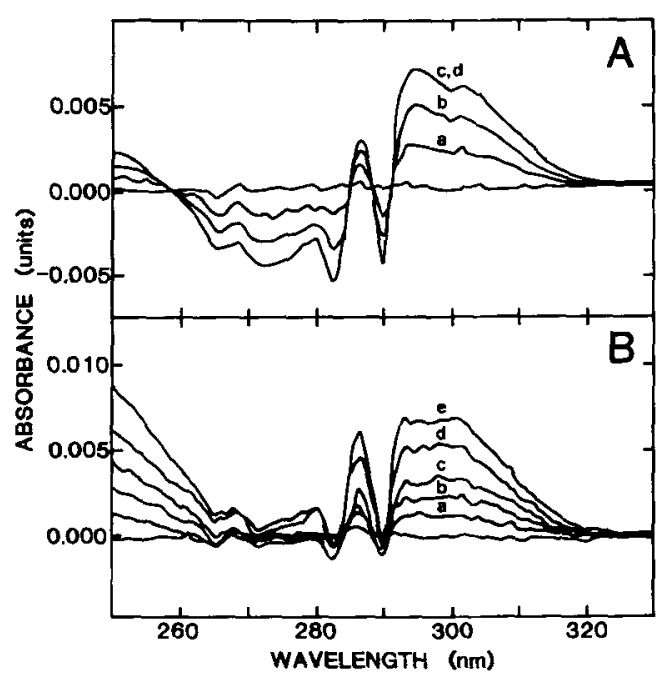

Figure 2. Difference absorption spectra of G2 (A: 12.8 $\mu \mathrm{M}$. B: $13.1 \mu \mathrm{M})$ induced at A) pH $5.0(0.1 \mathrm{M}$ sodium acetate) by acarbose: a) $4.5 \mu \mathrm{M}$, b) $8.9 \mu \mathrm{M}$, c) $13.3 \mu \mathrm{M}$, d) $150 \mu \mathrm{M}$ and B) $\mathrm{pH} 8.0(0.1 \mathrm{M}$ sodium phosphate) by acarbose: a) $2.2 \mu \mathrm{M}$, b) $4.5 \mu \mathrm{M}$, c) $6.7 \mu \mathrm{M}$, d) $8.8 \mu \mathrm{M}$, e) $150 \mu \mathrm{M}$. There was no further change in spectrophotometric signal upon addition of more ligand. 
Table I. Carboxamidomethylation and carboxymethylation of G2

\begin{tabular}{llc}
\hline Reaction mixture & $\begin{array}{l}\text { Histidine } \\
(\mathrm{mol} / \mathrm{mol})\end{array}$ & $\begin{array}{l}\text { Specific } \\
\text { activity } \\
(\%)\end{array}$ \\
\hline Iodoacetamide & 2.8 & 89 \\
Iodoacetamide + acarbose & 2.8 & 95 \\
Iodoacetate & 3.4 & 97 \\
Iodoacetate + acarbose & 3.2 & 99 \\
Control & 3.8 & 100 \\
Control + acarbose & 3.7 & 105 \\
\hline
\end{tabular}

The modification was performed at $\mathrm{pH} 4.3$ (see 2.3). The acarbose concentration was $0.5 \mathrm{mg} \cdot \mathrm{ml}^{-1}$. Acarbose and excess reagents were removed by dialysis (9) and the remaining histidine content measured by amino acid analysis. Enzyme activity was assayed using maltose.

\subsubsection{Localization of $\left[{ }^{14} \mathrm{C}\right]$ carboxamido- methyl-histidine}

Tryptic fragments of $\left[{ }^{14} \mathrm{C}\right]$ carboxamidomethylated $\mathrm{G} 2$ were separated on Bio-Gel P-100 (Fig. 3). Radiolabelled fragments were recovered in pool $\mathrm{B}$ in approx. $60 \%$ yield and subjected to RP-HPLC (Fig. 4). Rechromatography (43) of the radioactive peak 1 in Figure 4 resolved $\mathrm{Asp}_{245}-\mathrm{Arg}_{273}$ and $\mathrm{Thr}_{379}-\mathrm{Lys}_{404}$. Both sequences contain histidine, but only $\mathrm{Asp}_{245}-\mathrm{Arg}_{273}$ was radioactive ( $50 \%$ recovery) (Table III). It carried a stoichiometric amount of $\left[{ }^{14} \mathrm{C}\right]$ carboxamidomethyl-group and sequencing confirmed the absence of $\mathrm{His}_{254}$. 1-carboxymethyl-histidine wasidentified after hydrolysis (10), while neither 3-carboxymethyl- nor 1,3-dicarboxymethyl-histidine were detected. Subfragmentation by chymotrypsin (43) and RP-HPLC of material in peak $A$ in Figure 3 failed to identify further modified groups.

\subsubsection{Reactivity of other side chains}

Various reagents in large excesses were employed to modify lysyl, arginyl, tyrosyl, and methionyl residues, but only the carboxyl groups and tryptophanyl residues as found earlier seemed essential for activity and thermostability (Table IV) $(8,9,42,46)$.

Iodination or nitration reduced the activity by $40-50 \%$. The inactivation due to lactoperoxi-

Table II. The kinetic parameters of carboxamidomethylated G2

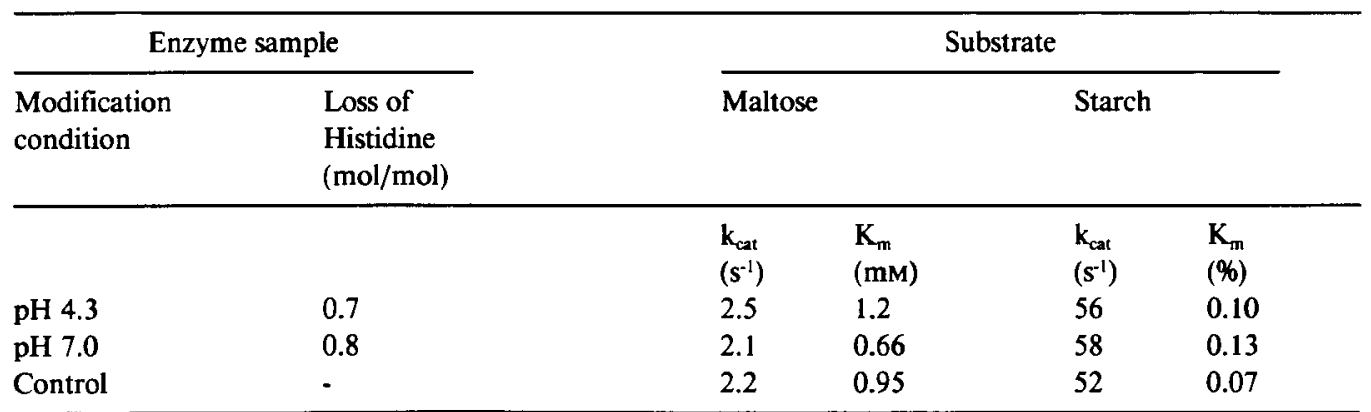

$\mathrm{k}_{\mathrm{cal}}$ is expressed in number of glucosyl bonds split per enzyme molecule per second. Assay conditions are described in section 2.2 . 


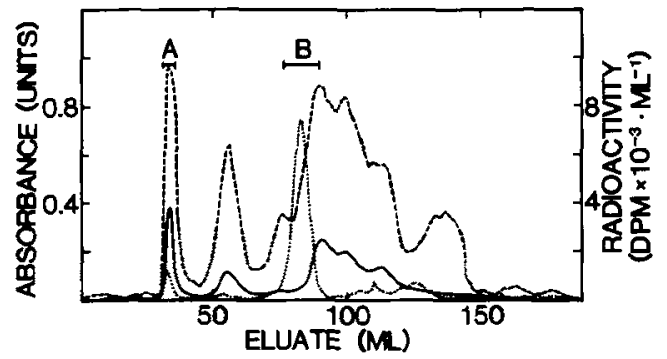

Figure 3. Separation of tryptic fragments $(5.4 \mathrm{mg})$ from $\left[{ }^{14} \mathrm{C}\right]$-carboxamidomethyl-2-pyridylethyl $\mathrm{G} 2$ on BioGel P-100. $A_{220}(-\cdots), A_{280}(-)$ and radioactivity (.......).

dase-catalyzed iodination was prevented in the presence of acarbose. The incorporated iodine was not determined quantitatively, but only 3 of the 21 tyrosines in $\mathbf{G} 2$ underwent nitration which normally is the more efficient of the methods. Thus unusually many tyrosyl groups in $\mathrm{G} 2$ behave as buried.

Only 3 amino groups were succinylated and 4 were carbamylated. Despite the larger fraction of unprotonated amino groups available at $\mathrm{pH}$ 10 , still only 5 lysyl residues reacted with $O$ methylisourea at that $\mathrm{pH}$ or with methyl acetimidate at $\mathrm{pH} 9$ (Table IV). Neither the two methionines (Table IV) nor the single free thiol group (B. SvENSSON, unpublished results) reacted in the native enzyme.

Endoglycosidase $\mathrm{H}$ released the two sugar moieties on $A_{s n_{171}}$ and $A_{s n_{395}}$ as indicated by the loss of 2 glucosamine residues and verified in the case of $\mathrm{Asn}_{395}$ by lack of neutral carbohydrate in the isolated fragment $\mathrm{Thr}_{379}-\mathrm{Lys}_{404}$ (data not shown). The deglycosylation neither affected the activity towards maltose and starch nor the thermostability. Moreover, treatment of $N$-deglycosylated G2 with either DEP at $\mathrm{pH} 6$ or iodoacetamide at $\mathrm{pH} 5$ resulted in fully active derivatives having a single modified histidyl residue.

\subsection{Titration of glucoamylase $\mathbf{G 2}$}

The low chemical reactivity in G2 of lysyl, histidyl, and tyrosyl side chains with expected

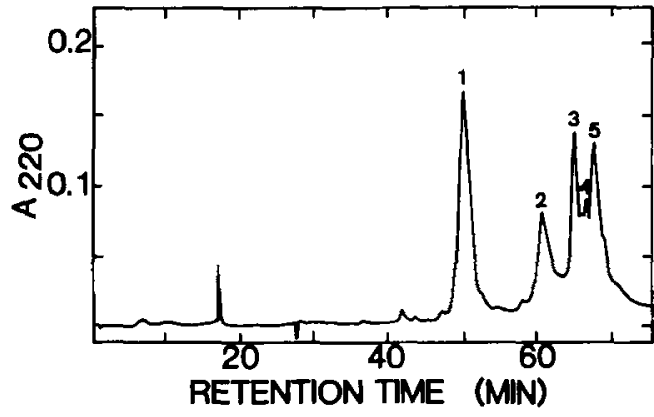

Figure 4. RP-HPLC of $60 \%$ of pool B (Fig. 3). Essentially all radioactivity that was eluted $(19,300 \mathrm{dpm}, 70 \%$ yield) was present in peak 1 .

surface-location motivated investigations of their degree of dissociation by potentiometric and spectrophotometric titration, respectively. Increasing the $\mathrm{pH}$ from 3 to 11 dissociates $45-47$ protons (Fig. 5). This number can be compared with a theoretical number of 61 calculated from a theoretical titration curve based on the amino acid composition $(43,45)$ and published intrinsic ionization constants of the side chains (4) and

Table III. Amino acid composition of the $\left[{ }^{14} \mathrm{Cl}\right.$-arboxamidomethylated peptide, Asp 245 -Asp $\left.273^{2}\right)$

\begin{tabular}{lc}
\hline Aspartic acid & $4.9(5)$ \\
Threonine & $2.9(3)$ \\
Serine & $2.9(3)$ \\
Glutamic acid & $2.3(2)$ \\
Proline & $3.4(3)$ \\
Glycine & $1.5(1)$ \\
Alanine & $3.0(3)$ \\
lsoleucine & $0.9(1)$ \\
Leucine & $2.2(2)$ \\
Phenylalanine & $2.0(2)$ \\
Histidine & $0.1(1)$ \\
Arginine & $0.8(1)$ \\
2-Pyridylethylcysteine & $0.8(2)$ \\
1-Carboxymethylhistidine & 0.8 \\
a) & The composition obtained from the amino sequence \\
(5, 43, 45) is given in parenthesis. \\
b) The radioactivity content of the peptide is 720 \\
dpm · nmol-1 which corresponds to equimolar incorpo- \\
ration of carboxamidomethyl group.
\end{tabular}


Table IV. Chemical modification of glucoamylase G2 from A. niger

\begin{tabular}{|c|c|c|c|c|}
\hline $\begin{array}{l}\text { Reagent } \\
\text { (conditions) }\end{array}$ & $\begin{array}{l}\text { Target } \\
\text { residue } \\
\text { (in G2) }\end{array}$ & $\begin{array}{l}\text { Number of } \\
\text { modified } \\
\text { residues }\end{array}$ & $\begin{array}{l}\text { Residual } \\
\text { activity } \\
(\%)\end{array}$ & $\begin{array}{l}t_{m} \\
\left({ }^{\circ} \mathrm{C}\right)\end{array}$ \\
\hline $\begin{array}{l}\text { Diethyl pyrocarbonate } \\
\text { (15 mM, pH 5-7) }\end{array}$ & His (4) & 1 & $102(105)$ & n.d. \\
\hline $\begin{array}{l}\text { lodoacetamide } \\
(0.10 \mathrm{M}, \mathrm{pH} 4-7)\end{array}$ & & 1 & $89-64$ & 68 \\
\hline $\begin{array}{l}\text { Iodoacetic acid } \\
(0.10 \mathrm{M}, \mathrm{pH} 4-7)\end{array}$ & & $0.4-0.6$ & $97-93$ & n.d. \\
\hline $\begin{array}{l}\text { Tetranitromethane } \\
(25 \mathrm{mM}, \mathrm{pH} 8)\end{array}$ & Tyr (21) & 3 & $60(82)$ & 64 \\
\hline $\begin{array}{l}\text { Triiodide }\left(\mathrm{I}_{3}^{-}\right) \\
(0.25 \mathrm{mM}, \mathrm{pH} 8)\end{array}$ & & n.d. & 56 & n.d. \\
\hline $\begin{array}{l}\text { Lactoperoxidase }{ }^{a)} \\
+ \text { acarbose }\left(0.1 \mathrm{mg} \cdot \mathrm{ml}^{-1}\right)\end{array}$ & & $\begin{array}{l}\text { n.d. } \\
\text { n.d. }\end{array}$ & $\begin{array}{l}50(50) \\
93\end{array}$ & $\begin{array}{l}\text { n.d. } \\
\text { n.d. }\end{array}$ \\
\hline $\begin{array}{l}\text { Potassium cyanate } \\
(0.24 \mathrm{M}, \mathrm{pH} 8)\end{array}$ & $\begin{array}{l}\text { Lys (10) } \\
\alpha-\mathrm{NH}_{2}(1)\end{array}$ & 4 & 70 & n.d. \\
\hline $\begin{array}{l}\text { Succinic anhydride } \\
(7 \times 10 \mathrm{~mm}, \mathrm{pH} 8)\end{array}$ & & $3^{d)}$ & 88 & 66 \\
\hline $\begin{array}{l}\text { O-Methylisourea } \\
(0.4 \mathrm{M}, \mathrm{pH} 10)\end{array}$ & & 5 & 85 & 68 \\
\hline $\begin{array}{l}\text { Methyl acetimidate } \\
(0.04 \mathrm{M}, \mathrm{pH} 9)\end{array}$ & & 5 & 90 & 68 \\
\hline $\mathrm{H}_{2} \mathrm{O}_{2}(0.74 \mathrm{M}, \mathrm{pH} 3)$ & Met (2) & 0 & 94 & n.d \\
\hline $\begin{array}{l}\text { Phenylglyoxal } \\
(0.16 \mathrm{M}, \mathrm{pH} 8)\end{array}$ & $\operatorname{Arg}(15)$ & 3 & 109 & n.d. \\
\hline $\begin{array}{l}\text { 2,3-Butanedione } \\
(0.10 \mathrm{M}, \mathrm{pH} 7-8\end{array}$ & & 6 & 80 & 66 \\
\hline $\begin{array}{l}N \text {-Bromosuccinimide }{ }^{\mathrm{b})} \\
(\mathrm{pH} \mathrm{4)}\end{array}$ & $\operatorname{Trp}(15)$ & 6 & 0 & \\
\hline + acarboșe & & 4 & 80 & 52 \\
\hline $\begin{array}{l}\text { 1-Ethyl-3-(4-azonia-4,4- } \\
\text { dimenthylpentyl)carbo- } \\
\text { diimide }^{c}(0.10 \mathrm{M}, \mathrm{pH} 6) \\
+ \text { acarbose }\end{array}$ & $\begin{array}{l}\text { Asp,Glu (53) } \\
a-\mathrm{COOH}(1)\end{array}$ & 16 & 0 & \\
\hline & & 12 & & 62 \\
\hline
\end{tabular}

The conditions for chemical modifications and analyses are described in section 2.3. The residual activity was measured with maltose as substrate, values within parenthesis are for starch hydrolysis.

$\mathrm{t}_{\mathrm{m}}=$ the temperature where glucoamylase looses $50 \%$ of the initial activity under the conditions employed (see section 2.2). $\mathrm{t}_{\mathrm{m}}$ of $\mathrm{G} 2$ is $67^{\circ} \mathrm{C}(42)$.

a) lactoperoxidase $(90 \mathrm{nM})$, iodide $(0.36 \mathrm{mM}), \mathrm{H}_{2} \mathrm{O}_{2}(5 \times 0.02 \mathrm{mM})$, pH 5.0 .

b) and c) are described in ref.s 9, 42 and 46.

d) The contribution from $\alpha-\mathrm{NH}_{2}$ substitution was not assessed. 


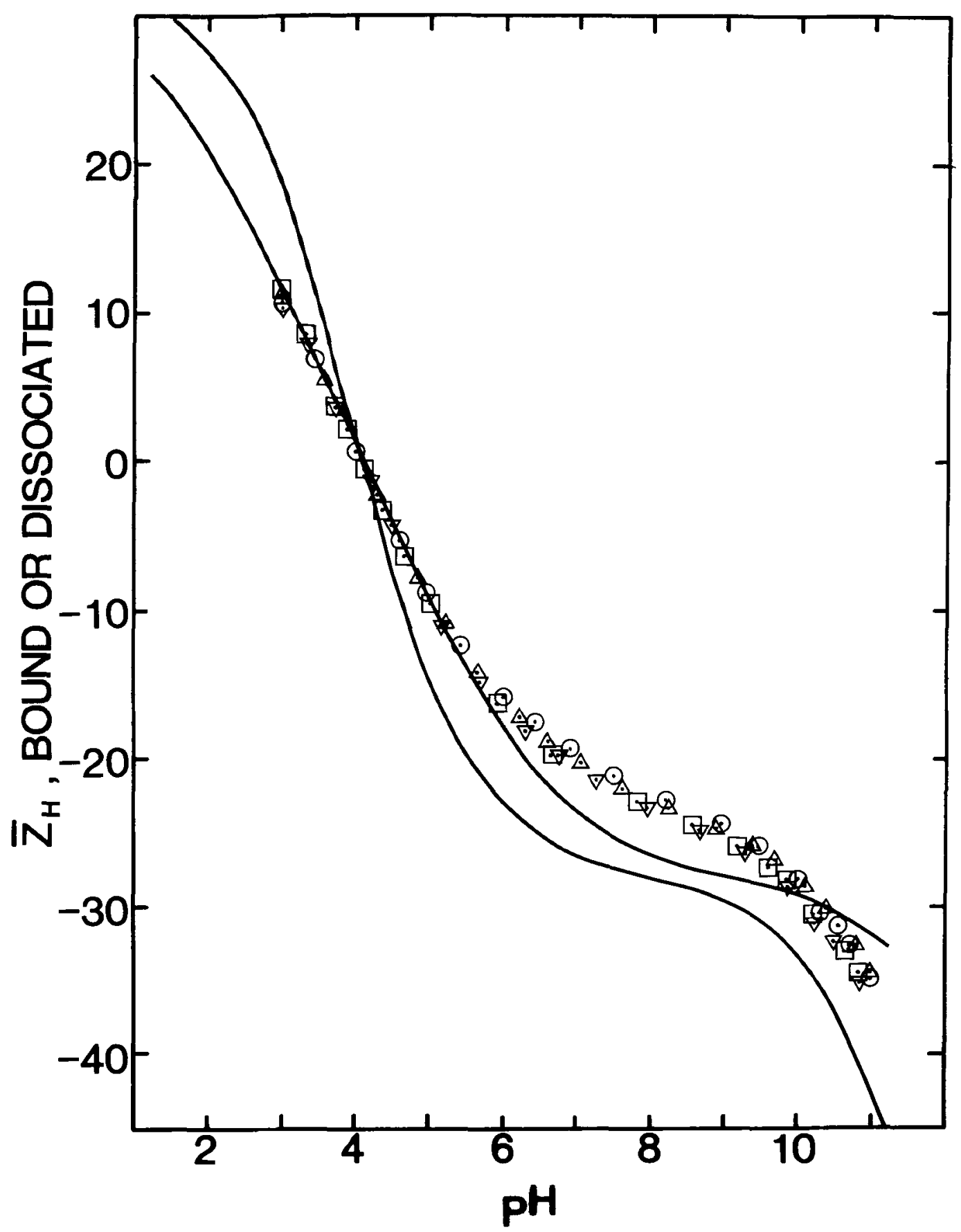

Figure 5. Potentiometric titration curve of $\mathrm{G} 2$ in $0.1 \mathrm{M} \mathrm{KCl}$. The theoretical curve calculated from $\overline{\mathrm{z}}_{\mathrm{H}}=+3$ to $\mathrm{Z}_{\mathrm{H}}$ $=-45$ using $\omega=0.025$ (see 2.6) and the curve through the experimental points ( 4 different experiments) calculated using $\omega=0.070$ are shown. 
peptide termini (36) with the number of $\mathrm{SH}$ groups set to one (B. SvENSSON, unpublished data). The relation $(\bar{Z}, p H)$ where $\bar{Z}$ is the mean net charge on the protein was solved graphically (data not shown) for a number of $\bar{Z}$ values setting:

$$
\overline{\mathrm{Z}}=\mathrm{Z}_{\max }-\sum \frac{\mathrm{n}_{\mathrm{i}} \mathrm{K}_{\text {int }} \cdot \mathrm{e}^{2 \omega \overline{\mathrm{z}}}}{\left[\mathrm{H}^{+}\right]+\mathrm{K}_{\text {int }} \cdot \mathrm{e}^{2 \omega \overline{\mathrm{z}}}}
$$

i.e. setting $K=K_{\text {int }} \cdot e^{2 \omega \bar{z}}(49)$

The theoretical curve (Fig. 5) was computed with an electrostatic interaction factor, $\omega$, of 0.025 calculated with the assumption that the charges were uniformly distributed on a spherical molecule of $36 \dot{A}$ diameter (22). The reference point of zero net charge was set at the calculated isoionic point, $\mathrm{pH} 4.1$, which agrees well with the value of $\mathrm{pH} 4.2$ determined experimentally by isoelectric focusing including known reference proteins (47). G2 was stable at $\mathrm{pH} 3$ for at least $2 \mathrm{~h}$, but had lost $25 \%$ activity after $2 \mathrm{~h}$ at $\mathrm{pH} 11$.

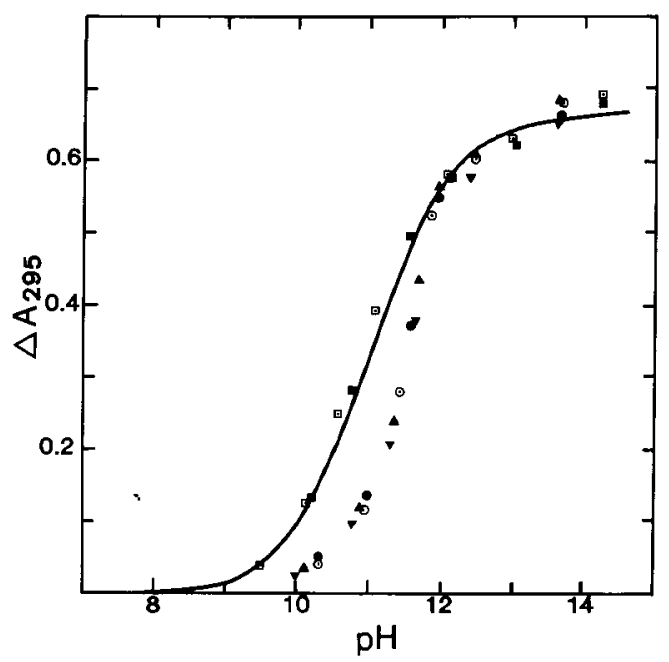

Figure 6. Spectrophotometric titration of G2 in $0.1 \mathrm{M}$ $\mathrm{KCl}$. The theoretical curve (solid line) was calculated using the $\bar{Z}, \mathrm{pH}$ values obtained as described in section 3.3 , an $\omega$ of 0.025 , an intrinsic pK value of tyrosine of 10.07 (4) and $\Delta \varepsilon_{295}$ of 2,330 (12). Experimental points are from different titrations of native $\mathrm{G} 2$ in $0.1 \mathrm{M} \mathrm{KCl}$ $(\Lambda, \nabla, \bullet, \odot)$ or of heat denatured $G 2$ in $6 \mathrm{M}$ urea and $0.1 \cdot \mathrm{M} \mathrm{KCl}(\square, \boldsymbol{\square})$.
Heat denaturation in urea exposes groups that are buried in the native conformation as shown in section 3.2. Consistent with this, spectrophotometric titrations indicated the average apparent $\mathrm{pK}_{\mathrm{a}}$ of the tyrosyl residues in native, but not in heat denatured $\mathrm{G} 2$ to be approx. half a unit higher than the theoretical value (Fig. 6).

\section{DISCUSSION}

In addition to tryptophanyl and carboxyl groups, tyrosyl and basic residues participate in substrate binding in Taka-amylase A (23) and pancreatic $\alpha$-amylase (6), which both are related to glucoamylase $(9,41)$. However, in $\mathbf{G} 2$ only few of the lysyl, arginyl, histidyl and tyrosyl side chains were susceptible to chemical modification, the largest effect being $40-50 \%$ decrease of the activity caused by tyrosine modification. Only a small effect was obtained by modification of other side chains and the reported increased resistance of other enzymes to thermal unfolding due to guanidination or acetamidation of $\varepsilon$-amino groups $(29,33)$ was not observed in these $\mathrm{G} 2$ derivatives.

Modification of histidyl residues was of special interest, because a short sequence near $\mathrm{His}_{391}$ in A. niger glucoamylase shows similarity with regions containing the substrate-binding $\mathrm{His}_{296}$ in Taka-amylase $\mathrm{A}$ and $\mathrm{His}_{299}$ in porcine pancreatic $\alpha$-amylase, respectively $(6,20,41)$. However, $\mathrm{His}_{391}$ in $\mathrm{G} 2$ even after deglycosylation of $\mathrm{Asn}_{395}$ seems to remain unmodified in the presence of high concentrations of iodoacetamide. The reactive group was $\mathrm{His}_{254}$ and its modification has no significance for catalysis similar to the modification of a single, unidentified histidyl residue by DEP. The carboxamidomethyl$\mathrm{His}_{254}$ derivative retained thermostability. Similarly, in related glucoamylases, only a single exposed histidyl residue was found $(31,35)$. This is in conflict with a reported modification of 3 histidines by DEP in the same enzyme leading to reduced affinity for soluble starch (18), thus it remains an open question whether histidines other than $\mathrm{His}_{254}$ might play a role in the mechanism of action.

The difference between the experimental and the theoretical titration curve in Figure 5 sug- 
gests that approx. 15 groups fewer than expected titrate between $\mathrm{pH} 3$ and 11 . This might be partially due to an unusually strong interaction between some of the ionizable residues, since a determination of $\omega$ from a plot of $\mathrm{pH}-\log \frac{\alpha}{1-\alpha}$ vs. $\bar{Z}$, where $\alpha$ is the fraction of the carboxylic acids that has lost protons, (22) indicated a value of 0.0705 . A curve based on this $\omega$ is included in Figure 5 but, as it can be seen, this titration curve is also inconsistent with the experimental curve. Such behaviour might be explained from incorrectness of the used model, viz. that the ionizable side chains are located in clusters instead of being uniformly distributed over a sphere, or, that some of the ionizable residues are engaged in salt-bridges which drastically displace their $\mathrm{pH}$-values. Due to the instability of the molecule at both high and low $\mathrm{pH}$ we have not been able to investigate this matter further. However, the results taken together indicate a low reactivity of the side chains of glucoamylase which might be connected with the high number of carbohydrate substituents which could also explain the high solubility of $\mathrm{G} 2$ in water. The occupancy of a large surface area by carbohydrates could sterically shield many side chains from chemical reagents and at the same time provide a microenvironment of dielectric constant intermediary to that of a hydrophobic interior of a protein and of water that still permits salt bridge formation, but destabilizes charges.

\section{ACKNOWLEDGMENTS}

We are grateful to Professor M. OTIESEN for helpful discussions and revision of the manuscript and to Dr. AA. HvidT for suggestions on protein titration experiments. Mss. BIRGITTE Marcussen, Edith Fløistrup and Sidsel EHLERS are thanked for excellent technical assistance and Dr. IB SVENDSEN, Mss. Bodil CoRNeliussen, LoNe SøRensen and Pia BReddam for amino acid and sequence analyses. The gift of acarbose from Drs. E. TRUSCHEIT, D. SCHMIDT and E. MölLER, Bayer A.G. is gratefully acknowledged.

\section{REFERENCES}

1. ALLEN, J.D.: Subsite mapping of enzymes: Application to polysaccharide depolymerases. Methods Enzymol. 64, 248-277 (1980)
2. Aoshima, H., T. Manabe, K Hiromi \& H. Hatano: Effect of photooxidation of bacterial liquefying $a$-amylase dependent on the degree of polymerization of linear substrates. Biochim. Biophys. Acta 341, 497-504 (1974)

3. AZARI, P.R.\& R.E. FEENEY: The resistance of conalbumin and its iron complex to physical and chemical treatments. Arch. Biochem. Biophys. 92, 44. 52 (1961)

4. BAKER, R.: Organic chemistry of biological compounds. Prentice-Hall, Inc., Englewood Cliffs, New Jersey (1971)

5. Boel, E. I. HJort, B. Svensson, F. Norris, K.E NORRIS \& N.P. FIIL: Glucoamylases G1 and G2 from Aspergillus niger are synthesized from two different but closely related mRNAs. EMBO J. 3 , 1097-1102 (1984)

6. Buisson, G., E. Duée, R. Haser \& F. Payan: Three dimensional structure of porcine pancreatic $\alpha$ amylase at $2.9 \dot{A}$ resolution. Role of calcium in structure and activity. EMBO J. 6, 3909-3916 (1987)

7. Chu, F.S., E. Crary \& M.S. Bergdoll: Chemical modification of amino groups in Staphylococcal enterotoxin B. Biochemistry 8, 2890-2896 (1969)

8. Clarke, A.J. \& B. Svensson: The role of tryptophanyl residues in the function of Aspergillus niger glucoamylase G1 and G2. Carlsberg Res. Commun. 49, 111-122 (1984)

9. Clarke, A.J. \& B. SvensSON: Identification of an essential tryptophanyl residue in the primary structure of glucoamylase G2 from Aspergillus niger. Carlsberg Res. Commun. 49, 559-566(1984)

10. Crestfield, A.M., W.H. Stein \& S. MoORE: Alkylation and identification of the histidine residues at the active site of ribonuclease. J. Biol. Chem. 238, 2413-2420 (1963)

11. Donoff, R.B. \& E.A. SWeeney: Photooxidation of hog pancreatic $\alpha$-amylase. J. Dent. Res. $49,800-$ 803 (1970)

12. DONOVAN, J.W.: Spectrophotometric titration of the functional groups of proteins. Methods Enzymol. 27, 525-548 (1973)

13. DuA. R.D. \& S. KochHAR: Active site studies on Bacillus amyloliquefaciens $\alpha$-amylase. Mol. Cell. Biochem. 66, 13-20 (1985)

14. ELöDI, P.: Role of histidyl residues in the activity of porcine pancreatic amylase. Acta Biochim. et Biophys. Acad. Sci. Hung. 7, $241-245$ (1972)

15. FIELDS, R.: The rapid determination of amino groups with TNBS. Methods Enzymol. 25, 464468 (1972)

16. GURD, F.R.N.: Carboxymethylation. Methods Enzymol. 25, 424-438 (1972)

17. HIRS, C.H.W.: The oxidation of ribonuclease with 
performic acid. J. Biol.Chem. 219,611-621 (1956)

18. HOSCHKE, A., E. LASZLO \&. HOLLO: A study of the role of histidine side-chains at the active center of amylolytic enzymes. Carbohydr. Res. 81, 145-156 (1980)

19. Kita, Y., S. Sakaguchi, Y. NitTa \& T. Watanabe: Kinetic study on chemical modification of Takaamylase A. J. Biochem. 92, 1499-1504 (1982)

20. MACGREgor, E.A. \& B. SvensSon: A super-secondary structure predicted to be common to several $\alpha$-1,4-D-glucan-cleaving enzymes. Biochem. J. 259, 145-152 (1989)

21. MARKLAND, F.S., A.D.E. BACHARACH, B.H. WEBER, T.C. OGRAdY, G.C. SAUNDERS \& N. UMEMURA: Chemical modification of yeast 3-phosphoglycerate kinase. J. Biol. Chem. 250, 1301-1310 (1975)

22. MARTIN, R.B.: Introduction to biophysical chemistry. McGraw-Hill Book Company. 79-84 (1964)

23. MatsuUra, Y., M. Kusunoki, W. Harada \& M. KAKUDO: Structure and possible catalytic residues of Taka-amylase A. J. Biochem. 95, 697-702 (1984)

24. Miles, E.W.: Modification of histidyl residues in proteins by diethyl pyrocarbonate. Methods Enzymol. 47, 431-442 (1977)

25. MORRISON, M: Lactoperoxidase-catalyzed iodination as a tool for investigation of proteins. Methods Enzymol. 70, 214-220 (1980)

26. MORRISON,M. \& G.S. BAYSE: Catalysis of iodination by lactoperoxidase. Biochemistry 9, 2995-3000 (1970)

27. NeumanN, N.P.. S.MOORE \& W.H.STEIN:Modification of the methionine residues in ribonuclease. Biochemistry 1, 68-75 (1962)

28. OBERFELDER, R.W. \& J.C. LEE: Measurement of ligand-protein interaction by electrophoretic and spectroscopic techniques. Methods Enzymol. 117, 381-399 (1985)

29. QAw, F.S. \& J.M. BREWER: Arginyl residues and thermal stability in proteins. Mol. Cell Biochem. 71, 121-127 (1986)

30. RIORDAN, J.F.: Functional arginyl residues in carboxypeptidase A. Modification with butanedione. Biochemistry 12, 3915-3923 (1973)

31. SAVEL'EV, A.N. \& L.M. FiRSov: Effect of modification of some amino acid radicals on enzymatic activity of glucoamylase from Aspergillus awamori. Biokhimiya 48, 1311-1318 (1982)

32. SCHACHTER, H. \& G.H. DixON: Preferential oxidation of the methionine residue near the active site of chymotrypsin. J. Biol. Chem. 239, 813-829 (1963)

33. Sexiguchi, T., S. Oshiro, E.M. GoINGo \& Y. NoSOH: Chemical modification of $\varepsilon$-amino groups in glutamine synthetase from Bacillus stearother- mophilus with ethyl acetimidate. J. Biochem. 85 , 75-78 (1979)

34. Setlow, B. \& T.E. Mansour: Studies on heart phosphofructokinase. J. Biol. Chem. 245, 55245533 (1970)

35. SHENoy, B.C., A.G. APPU RAO \& M.R. RAghaVENDRA RAO: Effect of chemical modification on structure and activity of glucoamylase from Aspergillus candidus and Rhizopus species. J. Biosci. 11, 339-350 (1987)

36. SOBER, H.A. (ed.) Handbook of Biochemistry. The Chemical Rubber Company, Cleveland, Ohio (1968)

37. SOKOLOVSKy, M., J.F. RIORDAN \& B.L. VALLEE: Tetranitromethane, a reagent for the nitration of tyrosyl residues in proteins. Biochemistry 5, 35823589 (1966)

38. SOMEYa, Y., H. Matsui \& S. Chiba: Chemical modification of a histidyl residue in the active site of brewer's yeast $\alpha$-glucosidase II. Agric. Biol. Chem. 48, 873-879 (1984)

39. STARK, G.R.: Modification of proteins with cyanate. Methods Enzymol. 25, 579-584 (1972)

40. SVENDSEN, I., B. MARTIN \& I. JonASSEN: Characteristics of Hiproly barley III. Amino acid sequences of two lysine-rich proteins. Carlsberg Res. Commun. 45, 79-85 (1980)

41. SVEnSSON, B.: Regional distant homology between amylases, $\alpha$-glucosidases, and transglucanosylases. FEBS Lett. 230, 72-76 (1988)

42. SVENSSON, B., A.J. ClaRKE \& I. SvendSEN: Influence of acarbose and maltose on the reactivity of individual tryptophanyl residues in glucoamylase from Aspergillus niger. Carlsberg Res. Commun. $51,61-73$ (1986)

43. Svensson, B., K. LarSen \& A. GunNarsson: Characterization of a glucoamylase G2 from Aspergillus niger. Eur. J. Biochem. 154, 497-502 (1986)

44. SVEnsSon, B., K LARSEN \& I. SVENDSEN: Amino acid sequence of tryptic fragments of glucoamylase G1 from Aspergillus niger. Carlsberg Res. Commun. 48, 517-527 (1983)

45. SVensson, B., K. Larsen, I. SVendsen \& E. Boel: The complete amino acid sequence of the glycoprotein, glucoamylase G1, from Aspergillus niger. Carlsberg Res. Commun. 48, $529-544$ (1983)

46. Svensson, B., H. Møller \& A. Clarke: Chemical modification of carboxyl groups in glucoamylase from Aspergillus niger. Carlsberg Res. Commun. 53, 331-341 (1988)

47. Svensson, B., T.G. Pedersen, I. SvendSEN, T.SAKaI \& M. OTTESEN: Characterization of two forms of glucoamylase from Aspergillus niger. Carlsberg Res. Commun. 47, 55-69 (1982)

48. TAKASHI, $K$.: The reaction of phenylglyoxal with 
K. HÁKANSSON \& B. SVENSSON: Chemical modification and $\mathrm{H}^{+}$-titration of glucoamylase

arginine residues in proteins. J. Biol. Chem. 243, 6171-6179 (1968)

49. TANFORD, C.: The interpretation of hydrogen ion titration curves of proteins. Adv. Prot. Chem. 17, 69-165 (1962)

Accepted by H. KLENOW
50. Tarentino, A.L., T.H. Plummer JR. \& F. Maley: The release of intact oligosaccharides from specific glycoproteins by endo- $\beta-\mathrm{N}$-acetylglucosaminidase H. J. Biol. Chem. 249, $818-824$ (1974) 